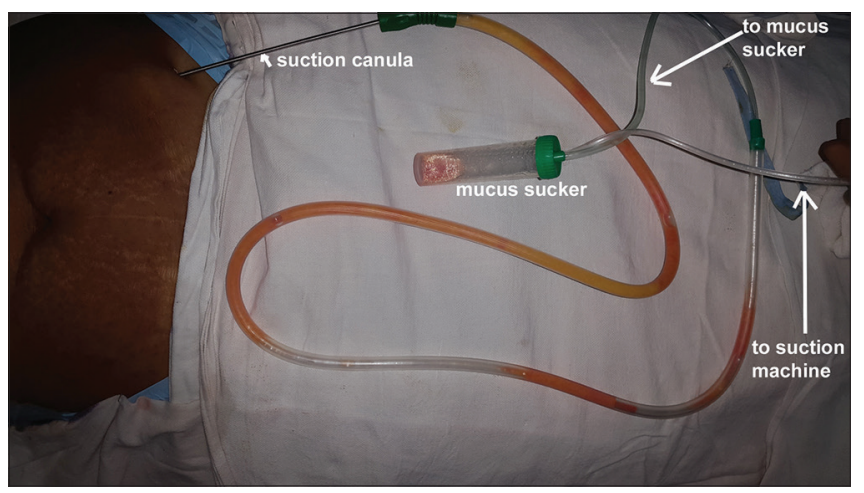

Figure 1: The working arrangement. The aspiration cannula is connected to a tube which drains fat into the mucous sucker. The suction is maintained by the tubing connected to the other opening in the mucous sucker

\title{
An alternative receptacle for fat harvest: The infant mucous sucker
}

\section{Sir,}

Fat grafting is a commonly performed aesthetic procedure. This involves harvesting fat under low pressure using syringe or high pressure using the suction machine. ${ }^{[1]}$ For harvesting a small amount of fat, a low-pressure system using syringe is good enough. The usual method of harvesting fat graft with 10 or $20 \mathrm{cc}$ syringes becomes tedious and repetitive if a larger amount of fat is

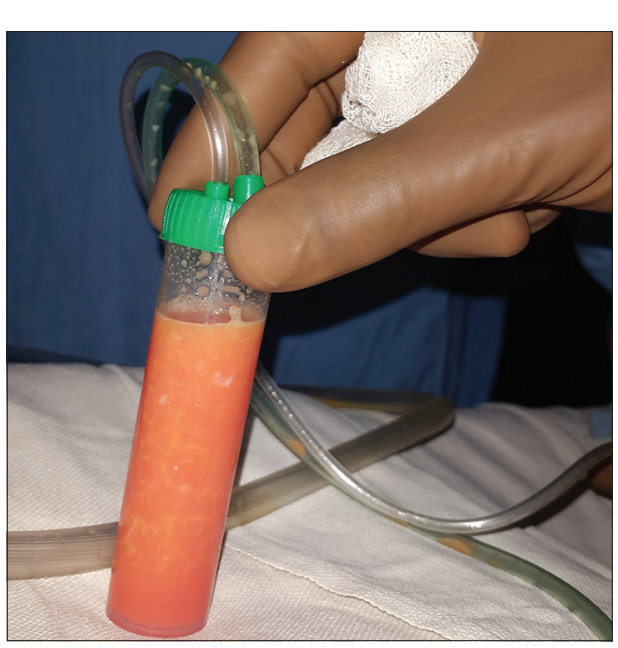

Figure 2: The infant mucus sucker showing aspirated fat

required. The powered suction apparatus is an option, but the aspirated fat goes directly to the suction bottle. One needs to buy a sterile, autoclavable container which is interposed in between the cannula and the machine so that the aspirated fat does not go directly to the suction machine. ${ }^{[2]}$

Our modification includes attaching the harvesting suction cannula to a sterile infant mucous sucker via a 2 cc syringe. The other end of this syringe is attached to the suction tubing. After suctioning, the fat gets accumulated in the mucous sucker [Figure 1]. We can then transfer it to the syringes for insertion after the receptacle is full [Figure 2].

The advantage of this modification is that it is easy to set up. It provides a disposable sterile receptacle, which is cheap at Rs. 40/unit. The capacity of the mucous sucker is $20 \mathrm{cc}$. We can harvest 150 to $200 \mathrm{cc}$ of fat with less 
hassle. It is a cheap alternative to the sterile autoclavable and reusable container and is universally available.

\section{Financial support and sponsorship}

Nil.

\section{Conflicts of interest}

There are no conflicts of interest.

\section{Satyaswarup Tripathy, Saurabh Rawat, Jerry R. John, Ramesh Kumar Sharma}

Department of Plastic Surgery, PGIMER, Chandigarh, India

Address for correspondence: Dr. Satyaswarup Tripathy, Department of Plastic Surgery,

PGIMER, Chandigarh, India. E-mail: dr.sstripathy@gmail.com

\section{REFERENCES}

1. Gir P, Brown SA, Oni G, Kashefi N, Mojallal A, Rohrich RJ. Fat grafting: Evidence-based review on autologous fat harvesting, processing, reinjection, and storage. Plast Reconstr Surg 2012;130:249-58.

2. Keck M, Kober J, Riedl O, Kitzinger HB, Wolf S, Stulnig TM, et al. Power assisted liposuction to obtain adipose-derived stem cells: Impact on viability and differentiation to adipocytes in comparison to manual aspiration. J Plast Reconstr Aesthet Surg 2014;67:e1-8.

This is an open access article distributed under the terms of the Creative Commons Attribution-NonCommercial-ShareAlike 3.0 License, which allows others to remix, tweak, and build upon the work non-commercially, as long as the author is credited and the new creations are licensed under the identical terms.

\begin{tabular}{|l|l|}
\hline \multicolumn{3}{|c|}{ Access this article online } \\
\hline Quick Response Code: & Website: \\
\hline & www.ijps.org \\
\cline { 2 - 2 } & Dol: \\
\hline
\end{tabular}

How to cite this article: Tripathy S, Rawat S, John JR, Sharma RK. An alternative receptacle for fat harvest: The infant mucous sucker. Indian J Plast Surg 2016;49:126-7. 